Ekuitas: Jurnal Pendidikan Ekonomi

Volume 7, Number 1, 2019, pp. 5 - 13

P-ISSN : 2354-6107 E-ISSN : 2549-2292

Open Access: https://ejournal.undiksha.ac.id/index.php/EKU

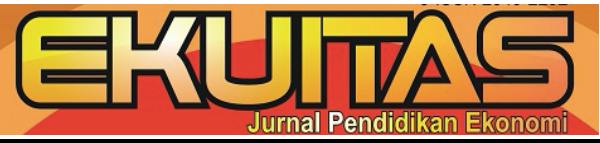

\title{
Pengelolaan Pendapatan Asli Desa Sebagai Landasan Pembangunan Ekonomi Pedesaan
}

\author{
Komang Adi Kurniawan Saputra ${ }^{1}$, Putu Budi Anggiriawan ${ }^{2}$, A.A. Ayu Erna Trisnadewi ${ }^{3}$, \\ Putu Gede Wisnu Permana Kawisana ${ }^{4}$, L.G.P. Sri Ekajayanti ${ }^{5}$
}

1,2,345Unversitas Warmadewa, Denpasar - Indonesia

\author{
A R T I C L E I N F O \\ Article history: \\ Received 01 February 2019 \\ Received in revised form \\ 08 May 2019 \\ Accepted 05 June 2019 \\ Available online 15 June \\ 2019 \\ Kata Kunci: \\ Pembangunan Ekonomi, \\ Pendapatan Desa, dan \\ Pengelolaan Pendapatan \\ Keywor|ds: \\ Development of Economy, \\ Income of Village, and \\ Managament Income
}

\begin{abstract}
A B S T R A K
Penelitian ini dilakukan untuk mengetahui pengelolaan pendapatan asli desa di Desa Kerobokan serta peran BUMDes untuk dapat meningkatkan pendapatan asli desa dan strategi pengelolaan pendapatan asli desa untuk meningkatkan perekonomian. Metode penelitian ini adalah metode deskriptif kualitatif. Data diperoleh melalui wawancara mendalam, observasi dan studi dokumen yang selanjutnya dianalisis dengan reduksi data, penyajian data, analisis data dan penarikan kesimpulan. Hasil penelitian menunjukan bahwa pengelolaan yang dilakukan oleh Pemerintah Desa Kerobokan sudah sesuai dengan prosedur pengelolaan, BUMDes berperan dalam meningkatkan pendapatan asli desa sehingga pemerintah desa dapat menyelenggarakan pembangunan yang berdampak pada perekonomian desa dan strategi yang dijalankan pemerintah desa lebih mengedepankan koordinasi dan kerjasama.
\end{abstract}

\section{A B S T R A C T}

This research was conducted to find out the management of village original income in Kerobokan Village and the role of BUMDes to be able to increase village original income and rural original income management strategy to improve the economy. This research method is qualitative descriptive method. Data obtained through in-depth interviews, observations and document studies are then analyzed by data reduction, data presentation, data analysis and conclusion. The result of the research shows that the management done by Kerobokan Village Government is in accordance with the management procedure, BUMDes play a role in increasing the village's original income so that the village government can carry out the development which impact on the village economy and the strategy implemented by the village government puts forward the coordination and cooperation.

Copyright (C) Ekuitas: Jurnal Pendidikan Ekonomi. All rights reserved.

\footnotetext{
* Corresponding author.

E-mail addresses: komangadikurniawan@gmail.com (Komang Adi Kurniawan Saputra)
} 


\section{Pendahuluan}

Pengelolaan pendapatan asli desa dilakukan dalam rangka penyelenggaraan pembangunan desa sebagai penambah dan pemasukan sumber pendapatan desa. Berdasarkan Undang-Undang Nomor 6 Tahun 2014 Pasal 77 tentang desa, pengelolaan kekayaan milik desa dilakukan untuk meningkatkan kesejahteraan dan taraf hidup masyarakat desa serta meningkatkan pendapatan desa. Permendagri Nomor 66 Tahun 2007 tentang perencanaan pembangunan desa menjelaskan bahwa pembangunan desa oleh pemerintah desa yang sebelumnya terbebani dengan program-program pembangunan dari pusat sekarang dapat lebih leluasa dan bebas dalam mengelola dan mengatur serta menentukan arah pembangunan desa secara mandiri.

Desa dituntut agar mandiri dalam menjalankan urusan pemerintahannya terutama dalam pengelolaan keuangan desa. Sumber pendapatan desa yang berasal dari pendapatan asli desa merupakan bentuk kemandirian desa dalam mengelola keuangan. Sehingga desa tidak tergantung dengan transfer dana yang berasal dari pemerintah daerah maupun pemerintah pusat. Dalam sistem pemerintahan yang ada saat ini, desa mempunyai peran yang strategis dalam membantu pemerintah daerah dalam proses penyelenggaraan pemerintahan, termasuk pembangunan dan pemberdayaan masyarakat sebagai langkah nyata pemerintah daerah dalam mendukung otonomi daerah di wilayahnya (Atmadja, et al, 2018). Pemerintah desa khususnya kepala desa dalam membangun dan mengembangkan desa harus mengetahui cara mengelola dan menjalankan pemerintahan dengan baik terutama dalam pengelolaan pendapatan. Baik tidaknya suatu pengelolaan bergantung pada tata kelola pemerintah desa itu sendiri, sehingga penting bagi pemerintah desa untuk mengetahui dan mengerti cara mengelola desa dengan baik. Mengingat dan menyadari adanya hambatan dalam pembangunan suatu daerah maka perlu suatu alternatif paradigma pembangunan yang baru (Sujarweni, 2015), dimana semua kebutuhan masyarakat terjamin sampai ke pelosok desa sehingga dibutuhkan daerah otonom untuk desa agar bisa mengelola sumber-sumber pembiayaannya untuk mensejahterakan masyarakat secara menyeluruh Saputra dan Julianto (2016).

Dalam pendapatan asli desa di Desa Kerobokan terdapat beberapa potensi yang belum dioptimalkan oleh pemerintah desa yang berpotensi sebagai pendapatan asli desa, diantaranya : optimalisasi pengembangan BUMDes, mendirikan pasar desa, serta potensi dalam BUMDes yaitu desa wisata dan mengoptimalkan potensi obyek wisata pantai. Pembentukan BUMDes dengan merangkul wirausaha yang ada di Desa Kerobokan diharapkan dapat mengoptimalkan pendapatan asli desa, dimana hasil usaha dari BUMDes tersebut akan diberikan kepada Desa. Potensi tersebut diharapkan dapat meningkatkan perekonomian Desa Kerobokan melalui pengelolaan yang dilakukan secara transparansi dan akuntabel (Atmadja dan Saputra, 2017). Transparansi berkaitan dengan keterbukaan atau lengkapnya informasi keuangan yang terbuka dan jujur kepada masyarakat berdasarkan pertimbangan bahwa masyarakat memiliki hak untuk mengetahui secara terbuka dan menyeluruh atas pertanggungjawaban dalam pengelolaan baik dalam pos pendapatan maupun secara menyeluruh. Dimana pengelolaan yang nantinya akan dilakukan yaitu mulai dari perencanaan sampai adanya suatu pertanggungjawaban dan realisasi yang dilakukan. Berdasarkan latar belakang inilah penulis mengangkat judul mengenai "Profesionalisme Pengelolaan Pendapatan Asli Desa Untuk Meningkatkan Pembangunan Ekonomi Pedesaan".

Berdasarkan latar belakang yang telah dijelaskan oleh peneliti dalam latar belakang penelitian, maka dapat dirumuskan masalah yang menjadi pokok bahasan penelitian ini adalah: (1) Bagaimanakah pengelolaan pendapatan asli desa di Desa Kerobokan?, (2) Bagaimana peran BUMDes untuk meningkatkan pendapatan asli desa di Desa Kerobokan?, (3) Bagaimanakah strategi pengelolaan pendapatan asli desa untuk meningkatkan perekonomian desa di Desa Kerobokan?.

\section{Metode}

\section{Desain penelitian}

Permasalahan yang akan dikaji oleh peneliti merupakan masalah yang bersifat sosial dan dinamis. Oleh karena itu, peneliti memilih menggunakan metode penelitian kualitatif untuk menentukan cara mencari, mengumpulkan, mengolah, dan menganalisis data hasil penelitian tersebut. Penelitian kualitatif ini dapat digunakan untuk memahami interaksi sosial, misalnya dengan wawancara mendalam sehingga akan ditemukan pola-pola yang jelas. Format desain penelitian kualitatif terdiri dari tiga model, yaitu format deskriptif, format verifikasi, dan format grounded research. Dalam penelitian ini digunakan metode kualitatif dengan desain deskriptif, yaitu penelitian yang memberi gambaran secara cermat mengenai individu atau kelompok tertentu tentang keadaan dan gejala yang terjadi. Selanjutnya peneliti akan memberikan gambaran dengan secara cermat tentang fenomena yang terjadi mengenai bagaimana 
pengelolaan pendapatan asli desa untuk meningkatkan pembangunan perekonomian desa pada Desa Kerobokan.

\section{Subyek dan Obyek Penelitian}

Subyek penelitian ini adalah Pengurus di Kantor Desa Kerobokan, yang terdiri dari Kepala Desa, Ketua BPD, Sekretaris Desa, serta Ketua Pengelola BUMDes. Fokus utama dalam penelitian ini adalah pengelolaan pendapatan asli desa dalam meningkatkan pembangunan perkonomian desa. Objek dalam penelitian ini adalah pengelolaan pendapatan asli desa. Dimana pengelolaannya meliputi pada proses penyusunan perencanaan yang akan dilaksanakan, dilanjutkan dengan penyusunan anggaran operasional kemudian realisasi dan pertanggungjawaban anggaran tersebut.

\section{Teknik Pengumpulan Data}

Teknik pengumpulan data merupakan cara yang digunakan peneliti untuk mendapatkan data dalam suatu penelitian. Pada penelitian kali ini peneliti memilih jenis penelitian kualitatif maka data yang diperoleh haruslah mendalam, jelas dan spesifik. Selanjutnya dijelaskan oleh Sugiyono (2009) bahwa pengumpulan data dapat diperoleh dari hasil observasi, wawancara, dokumentasi, dan gabungan/triangulasi. Pada penelitian ini peneliti menggunakan teknik pengumpulan data dengan cara observasi, dokumentasi, dan wawancara.

\section{Observasi}

Observasi adalah pengamatan yang dilakukan dengan sengaja dan sistematis terhadap aktivitas individu atau obyek lain yang diselidiki. Adapun jenis-jenis observasi tersebut diantaranya yaitu observasi terstruktur, observasi tak terstruktur, observasi partisipan, dan observasi nonpartisipan. Dalam penelitian ini, sesuai dengan objek penelitian maka, peneliti memilih observasi partisipan. Observasi partisipan yaitu suatu teknik pengamatan dimana peneliti ikut ambil bagian dalam kegiatan yang dilakukan oleh objek yang diselidiki. Observasi ini dilakukan dengan mengamati dan mencatat langsung terhadap objek penelitian, yaitu dengan mengamati kegiatan-kegiatan yang ada di Kantor Desa Kerobokan.

\section{Wawancara}

Dalam teknik pengumpulan menggunakan wawancara hampir sama dengan kuesioner. Wawancara itu sendiri dibagi menjadi 3 kelompok yaitu wawancara terstruktur, wawancara semi-terstruktur, dan wawancara mendalam (in-depth interview). Disini peneliti memilih melakukan wawancara mendalam, ini bertujuan untuk mengumpulkan informasi yang kompleks, yang sebagian besar berisi pendapat, sikap, dan pengalaman pribadi.

3. Studi Pustaka

Yaitu Teknik pengumpulan data yang dilakukan dengan mempelajari buku-buku referensi, laporanlaporan, majalah-majalah, jurnal-jurnal dan media lainnya yang berkaitan dengan objek penelitian.

4. Dokumentasi

Dokumen menurut Sugiyono (2009) merupakan catatan peristiwa yang sudah berlalu. Dokumen yang digunakan peneliti disini berupa foto, gambar, serta data-data mengenai Kepala Desa Kerobokan maupun aparat desa yang didapatkan dari Kantor Desa Kerobokan.

\section{Metode Analisis Data \\ Reduksi Data}

Reduksi data meliputi berbagai kegiatan yang bertujuan untuk mempertajam analisis. Proses wawancara terhadap informan terkadang keluar dari konteks panduan wawancara yang telah disusun. Reduksi pada hasil wawancara ini dilakukan dengan menghilangkan jawaban-jawaban informan yang keluar dari konteks pertanyaan pedoman wawancara. Maka dari itu, proses reduksi berkaitan dengan pemilahan data yang dilihat dari relevansinya dengan pertanyaan penelitian. Bahkan dalam suatu reduksi akan dibuat suatu narasi awal yang bersifat tentatif. Hal ini penting dilakukan dalam konteks pemfokusan penggalian data, yang nantinya akan mengarah pada pengujian proposisi penelitian atau menambah variasi penjelasan maupun pemaknaan yang sudah ada. Kesemuannya itu tidak dapat dilepas dari bangunan landasan teori yang sudah dibuat. Landasan teori memberikan arah tentang data apa yang dikumpulkan dan bagaimana membangunnya dalam bentuk narasi.

Berkenaan dengan itu, maka triangulasi data sangat penting dilakukan dalam proses reduksi. Hal ini penting dilakukan untuk menambah validitas data lebih terjamin keabsahannya. Data yang didapat dari hasil wawancara dan observasi dapat pula ditriangulasikan dengan data dokumen, begitu sebaliknya sehingga data yang didapat lebih banyak dan keabsahannya lebih kuat. 


\section{Analisis Penarikan Kesimpulan}

Dalam konteks penelitian ini, analisis dilakukan dengan merujuk pada proposisi yang telah dibuat sebelumnya. Proposisi ini diuji untuk mengetahui sejauh mana dapat dipertahankan melalui bukti-bukti dalam menjawab pertanyaan penelitian. Selanjutnya hasil analisis, dimanfaatkan dalam penarikan suatu kesimpulan penelitian yang menguraikan makna subjektif, temuan konsep atas permasalahan yang diteliti. Selain itu juga, kegiatan pengumpulan data, reduksi data penarikan kesimpulan merupakan rangkaian terkait sampai mendapatkan hasil penelitian akhir yang berisfat holistik dan sarat makna dalam konteks pemberian jawaban terhadap masalah yang dikaji. Temuan yang didapat dalam penelitian ini akan dipaparkan dalam bentuk laporan hasil penelitian. Isi laporan penelitian ini berupa narasi yang mengandung hasil analisis data dari hasil observasi (pengamatan), wawancara dan dokumentasi.

\section{Hasil dan pembahasan}

\section{Optimalisasi Pengelolaan Pendapatan Asli Desa}

Komponen pendapatan asli desa terdiri dari pajak, retribusi, hasil perusahaan milik daerah dan hasil pengelolaan kekayaan daerah. Keempat komponen tersebut sangat penting dan masing-masing memberikan konstribusi bagi penerimaan pendapatan asli desa. Masing-masing desa terdapat beberapa potensi yang dijadikan sebagai sumber pendapatan asli desa yang dapat meningkatkan komponen tersebut. Dapat berupa pasar desa, pasar hewan maupun yang lainnya sesuai yang dimiliki oleh desa. Kepala Desa Kerobokan, Putu Wisnu Wardana mengatakan:

"Untuk sumber-sumber asli pendapatan asli desa di Kerobokan yang pertama bersumber dari pengelolaan obyek wisata pantai. Yang kedua BUMDes, sumber penghasilan sisa hasil bersih masuk ke desa selaku sumber pendapatan asli desa dari sisa alokasi hasil usaha, terus sumber-sumber yang lain itu tidak mengikat, itu pun ada beberapa usaha-usaha yang sekiranya seperti pengelolaan sampah dan sebagainya itu masuk sebagai sumber pendapatan asli desa, terus yang lainnya juga sumbangan-sumbangan tidak mengikat dari perusahaan yang pada saat kita melakukan kegiatan 17 Agustus atau kegiatan pembangunan dan sebagainya itu tidak istilahnya mengikat, itu hanya sumbangsih kepada pembangunan desa."

Sumber-sumber tersebut nantinya akan menambah pendapatan desa untuk menunjang kegiatan operasional desa (Sujarweni, 2015). Sumber-sumber yang digunakan dalam membiayai kegiatan pembangunan berasal dari pendapatan asli desa, alokasi dana desa, dan bantuan keuangan dari Pemerintah Kabupaten Buleleng (Saputra dan Julianto, 2016). Pendapatan asli desa tersebut akan dialokasikan ke desa dengan persentase yang sudah ditetapkan oleh pemerintah desa. APBDesa, diharapkan akan mampu mendorong roda pemerintahan di tingkat desa, termasuk untuk menanggapi kebutuhan-kebutuhan yang mampu ditangani di tingkat desa. APBDesa yang memadai juga dapat mendorong partisipasi warga lebih luas pada proses-proses perencanaan dan penganggaran pembangunan. Partisipasi warga yang tidak terakomodasi dalam APBD, dengan adanya APBDesa dapat menjawab partisipasi warga yang bersifat mikro dan mampu ditangani pada level desa. Supaya alokasi dana desa dalam pelaksanan APBDesa benar-benar diimplementasikan, perlu dilakukan proses penguatan pemerintahan desa (Pemerintah Desa dan Badan Permusyawaratan Desa) dalam mengelola keuangan desa, khususnya peningkatan Pendapatan Asli Desa (PADes) yang berorientasi kepada peningkatan kesejahetraan masyarakat desa (Yabbar dan Hamzah, 2015). Pengelolaan yang baik merupakan elemen penting untuk memastikan organisasi bekerja sesuai dengan kepentingan anggotanya.

1. Perencanaan (Planning) adalah pemilihan fakta-fakta dan usaha menghubungkan fakta satu dengan lainnya, kemudian membuat perkiraan dan peramalan tentang keadaan dan perumusan tindakan untuk masa yang akan datang yang sekiranya diperlukan untuk mencapai hasil yang dikehendaki. Seperti yang dikatakan oleh Kepala Desa Kerobokan menegaskan:

"Sistem perencanaan tetap dengan dasar musyawarah. Melibatkan BPD maupun desa pakraman dan desa dinas. Setidaknya sebelum mengambil keputusan dalam perencanaan itu lewat musyawarah desa."

2. Pengorganisasian (Organizing) diartikan sebagai kegiatan mengaplikasikan seluruh kegiatan yang harus dilaksanakan antara kelompok kerja dan menetapkan wewenang tertentu serta tanggung 
jawab sehingga terwujud kesatuan usaha dalam pencapaian tujuan yang telah ditetapkan. Hal tersebut sejalan dengan pernyataan dari Kepala Desa Kerobokan:

“.... Sumber-sumber yang lain dengan pengorganisasiannya membentuk team khusus melalui surat keputusan perbekel. SKnya dibebankan kepada PAD Desa untuk membiayai sumber-sumber yang berkait dengan sumber pengeluaran, dan yang lainnya sama juga membentuk team khusus juga."

3. Penggerakan (Actuating) adalah menempatkan semua anggota daripada kelompok agar bekerja secara sadar untuk mencapai suatu tujuan yang telah ditetapkan sesuai dengan perencanaan dan pola organisasi.

4. Pengawasan (Controlling) diartikan sebagai proses penentuan yang dicapai, pengukuran dan koreksi terhadap aktivitas pelaksanaan dan bilamana perlu mengambil tindakan korektif terhadap aktivitas pelaksanaan dapat berjalan menurut rencana. Terkait dengan pemaparan dari Ketua BPD Desa Kerobokan, menyatakan:

"Disamping mengawasi, perbekel juga menyampaikan laporan kepada saya, laporan keterangan perbekel terkait pertanggungjawaban pengelolaan keuangan atau pendapatannya itu sebelum disampaikan ke masyarakat di desa."

Hal senada juga disampaikan oleh Kepala Desa Kerobokan, menegaskan:

"Pengawasannya jelas team khusus itu dengan BPD secara langsung diawasi oleh pemerintah desa."

Sebagian besar pengelolaan pendapatan asli desa di Desa Kerobokan sudah dikelola dengan teratur dimana pemerintah desa membentuk team khusus untuk melakukan pengawasan dan pertanggungjawaban kepada pihak pemerintah desa yang dimana team khusus tersebut diberikan Surat Keputusan (SK) yang dikeluarkan oleh perbekel desa. Pendapatan asli desa dapat dioptimalkan melalui berbagai tindakan maupun proses yang nantinya akan dapat meningkatkan pendapatan itu sendiri. Dimana dengan meningkatnya pendapatan asli desa, maka akan dapat menambah atau meningkatkan perekonomian desa. Tindakan yang digunakan dapat berupa pengelolaan terhadap pendapatan asli desa sendiri dengan meningkatkan potensi-potensi yang dapat menjadi pendukung dalam pendapatan asli desa (Dewi, dkk, 2017). Menurut Kepala Desa Kerobokan tentang optimal atau belum dalam hal pengelolaan pendapatan asli desa yang dilakukan, menegaskan:

"Sumber pendapatan yang dibilang optimal baru sedikit, kita masih lakukan pendekatan ke DKP (Dinas Kebersihan dan Pertamanan) untuk pengelolaan sampah. Karna ini ibaratnya sudah punya lahan untuk desa sendiri anggapannya tahun depan biar dapat pemisahan pengelolaan sampah yang terjadi dengan pihak BUMDes dengan membentuk Bank Sampah."

Pengelolaan pendapatan asli desa yang dilakukan oleh Desa Kerobokan dapat dioptimalkan dengan bekerja sama dengan pihak BUMDes membentuk bank sampah yang dipisahkan pengelolaannya. Pengelolaan tersebut juga sudah menerapkan asaz pengelolaan keuangan desa yang transparansi dan akuntabel. Pengelolaan setidaknya harus diketahui oleh semua masyarakat desa dalam hal kejujuran pemerintah desa dalam mengalokasikan dana baik dari pendapatan asli desa maupun dari dana pemerintah pusat.

Berdasarkan hasil wawancara dan observasi, hal tersebut didukung oleh pernyataan dari Kepala Desa Kerobokan yang menegaskan:

"Dalam realisasi penggunaan anggaran kuncinya terbuka dengan memasang papan-papan kegiatan. Satu sumber alokasi baik itu dana desa, alokasi dana desa, pembagian pajak, retribusi sampai sumber pendapatan asli desa itu pun kita susun sesuai dengan program, pengadaan-pengadaan sarana perkantoran terus yang kedua bidangnya adalah pembinaan masyarakat itu melibatkan seluruh pihak baik PKK, Karang Taruna terus pembentukan forum umat beragama dan sebagainya. Terus yang ketiga adalah pemberdayaan masyarakat dengan adanya pelatihan dengan adanya forum kerukunan umat beragama kita berikan saling hormati, toleransi, yang ketiga itu pembangunan infrastruktur ." 
Hal senada juga dikatakan oleh Sekretaris Desa Kerobokan, yakni sebagai berikut:

\begin{abstract}
"Pertanggungjawaban itu dibuat oleh Desa dan disampaikan ke BPD setelah disetujui BPD atau disepakati baru disampaikan kepada BPD namanya laporan keterangan perbekel, nanti itu disebar luaskan ke masing-masing dusun. Kadang juga kepala desa mengundang masyarakat kesini, terutama BPD, Kepala Dusun, Ketua Kelompok dan disanalah kepala desa menyampaikan pertanggungjawabannya."
\end{abstract}

Proses penyelenggaraan pemerintahan desa diatur dalam UU No. 5 Tahun 1979. Berdasarkan struktur organisasi tersebut dapat dilihat bahwa unsur pemerintahan desa terdiri dari kepala desa dan lembaga musyawarah desa. Kepala desa sebagai pucuk pimpinan desa, dibantu oleh sekretaris desa dan kepala dusun. Menurut perundang-undangan, kepala desa memegang peranan sebagai lembaga eksekutif, untuk membentuk peraturan, pelaksanaan kebijakan, penyelesaian sengketa, melakukan pembinaan masyarakat, juga berkewajiban untuk melaksanakan pemerintahan yang transparan, akuntabel, dan professional, efektif, efisien, dan bersih. Melalui UU No. 6 Tahun 2014, masa jabatan kepala desa diperpanjang menjadi selama 6 (enam) tahun untuk satu kali masa jabatan, dan bisa dipilih kembali sampai tiga kali. Dalam melakukan fungsi penyelenggaraan pemerintahan, kepala desa dibantu sekretaris desa yang mengurusi urusan administrasi dan kesekretariatan desa. Kepala desa juga dibantu untuk menangani masing-masing bidang urusan khusus, oleh kepala urusan (kaur). Sementara kepala dusun berfungsi sebagai pelaksana kebijakan kepala desa, untuk disosialisasikan dan diterapkan di wilayahnya (dusun).

Dalam penyelenggaraan pemerintahan desa, posisi kepala desa disejajarkan dengan lembaga musyawarah desa, yakni Badan Permusyawaratan Desa, yang berfungsi sebagai legislatif di tingkat desa. Sama halnya dengan Dewan Perwakilan Rakyat, BPD juga memiliki fungsi anggaran, legislasi, dan pengawasan, dalam tata kelola pemerintahan desa. Badan Permusyawaratan Desa juga berkewajiban untuk menampung dan menyalurkan aspirasi masyarakat, sehingga pemerintahan dan pembangunan desa selalu sesuai dengan apa yang menjadi kebutuhan masyarakat desa. Jika dikaitkan dengan perwujudan pemerintahan yang transparan dan akuntabel, peran BPD sebagai pengawas menjadi sangat penting. Fungsi pengawasan yang dipangku BPD, bisa menjadi salah satu instrumen perwujudan tata kelola pemerintahan yang baik. Sehingga good government governance bisa tercipta dari lingkup pemerintahan yang terdekat dengan masyarakat (Atmadja and Saputra, 2018).

Secara singkat, penyelenggaraan pemerintahan bisa dipaparkan bahwa sekretaris desa, kepala urusan, kepala dusun, bertanggungjawab kepada kepala desa sebagai puncak pimpinan pemerintahan desa (Rasjid dan Blongkod, 2016). Sementara BPD berperan sebagai pengawas dan bekerjasama dengan kepala desa untuk urusan pemerintahan desa, dalam upaya mensejahterakan masyarakat desa. Setiap tahun, kepala desa wajib untuk memberikan laporan penyelenggaraan pemerintahan berupa Laporan Pertanggungjawaban (LPJ) kepada bupati melalui camat, untuk menilai penyelenggaraan pemerintahan desa dan memutuskan pembinaan lebih lanjut. Dan Laporan Keterangan Pertanggungjawaban (LKPJ) kepada Badan Permusyawaratan Desa (BPD) sebagai pengawas pemerintah desa.

Sumber pendapatan Desa Kerobokan dalam membiayai kegiatan pembangunan berasal dari pendapatan asli desa, Alokasi Dana Desa (ADD) dan bantuan keuangan dari Pemerintah Daerah Kabupaten Buleleng. Sumber pendapatan desa yang berupa Pendapatan Asli Desa (PADes) dapat dioptimalkan oleh pemerintah desa agar dapat menambah jumlah pendapatan. Dengan pengelolaan yang baik, hal ini mengindikasikan bahwa organisasi telah memenuhi persyaratan dan memiliki perangkat minimal untuk memastikan kredibilitas, integritas dan otoritas sebuah institusi dalam membangun aturan, membuat keputusan serta mengembangkan program dan kebijakan yang merefleksikan pandangan dan kebutuhan anggota. Utamanya, melalui pengelolaan yang baik, organisasi memelihara kepercayaan anggota meningkatkan reputasi, serta memengaruhi anggota-anggotanya melalui interaksi yang dibangunnya.

Sebagai desa yang agraris dan cocok di bidang pertanian, serta termasuk sebagai desa wisata, masih banyak potensi di Desa Kerobokan yang dapat dijadikan sebagai sumber pendapatan asli desa seperti adanya kerjasama antara wisata-wisata yang sudah berkembang di Desa Kerobokan dengan BUMDes Desa Kerobokan agar dapat lebih meningkatkan pendapatan desa. Dalam hal pengelolaan pendapatan asli desa yang dilakukan pemerintah desa di Desa Kerobokan sudah sesuai dengan pengelolaan pada umumnya dari perencanaan sampai pada tahap pengawasan yang dilakukan berdasarkan wawancara yang dilakukan. 


\section{Peran BUMDes dalam Meningkatkan Pendapatan Asli Desa}

BUMDes merupakan lembaga usaha yang bergerak dalam bidang pengelolaan aset-aset dan sumberdaya ekonomi desa dalam kerangka pemberdayaan masyarakat desa.Pengaturan BUMDes diatur di dalam Pasal 213 ayat (1) UU No. 32 Tahun 2004, bahwa desa dapat mendirikan Badan Usaha Milik Desa sesuai dengan kebutuhan dan potensi desa. Selain itu juga diatur dalam Peraturan Pemerintah Nomor 72 Tahun 2005 tentang desa, yang didalamnya mengatur tentang BUMDes, yaitu pada Pasal 78 - 81, Bagian Kelima tentang Badan Usaha Milik Desa, serta yang terakhir dalam Peraturan Menteri Dalam Negeri Nomor 39 Tahun 2010 tentang Badan Usaha Milik Desa. Tujuan BUMDes yaitu mengoptimalkan pengelolaan aset-aset desa yang ada, memajukan perekonomian desa, serta meningkatkan kesejahteraan masyarakat desa. Sifat usaha BUMDes adalah berorientasi pada keuntungan. Sifat pengelolaan usahanya adalah keterbukaan, kejujuran, partisipasif dan berkeadilan. Fungsi BUMDes adalah: sebagai motor penggerak perekonomian desa, sebagai lembaga usaha yang menghasilkan Pendapatan Asli Desa (PADes), serta sebagai sarana untuk mendorong percepatan peningkatan kesejahteraan masyarakat desa.

Dengan kehadiran BUMDes ini diharapkan desa menjadi lebih mandiri dan masyarakatnya pun menjadi lebih sejahtera. Peran BUMDes tersebut berdasarkan wawancara dengan ketua pengelola BUMDes, sudah sesuai untuk dapat meningkatkan pendapatan asli desa yang nantinya akan dapat menambah pendapatan desa yang digunakan untuk kegiatan pembangunan desa guna meningkatkan perekonomian desa di Desa Kerobokan. Dengan lebih menggali potensi-potensi yang ada di Desa Kerobokan, akan memungkinkan adanya peningkatan juga di dalam pendapatan asli desa tersebut. Karena tidak dipungkiri desa tidak dapat terlepas dari Pendapatan Transfer.Pendapatan Transfer merupakan retribusi terbesar yang diperoleh desa untuk melaksanakan pembangunan yang bersifat jangka panjang, seperti pembuatan jalan.Dan jumlahnya pun terlampau sangat besar dibandingkan pendapatan yang lainnya. Dana dari pendapatan asli desa hanya digunakan untuk pembangunan yang bersifat menengah, seperti perbaikan kantor BUMDes. Maka dari itu, dengan makin bergantungnya desa terhadap dana dari pemerintah, peran BUMDes diperlukan untuk meningkatkan Pendapatan Asli Desa agar Desa dapat memanfaatkan potensi-potensi yang ada di Desa Kerobokan dengan baik sehingga dapat meningkatkan jumlah pendapatan asli desa pada khususnya dan pendapatan desa pada umumnya.

Pengelolaan Pendapatan Asli Desa dalam Perekonomian Desa

UU No. 6 tahun 2014 pasal 77 bahwa pengelolaan kekayaan milik desa dilakukan untuk meningkatkan kesejahteraan masyarakat desa serta meningkatkan pendapatan desa. Dalam rangka mendukung penyelenggaraan otonomi desa (Saputra, dkk, 2018), maka perlu untuk meningkatkan dan mengembangkan segala potensi-potensi yang ada di Desa Kerobokan, baik potensi alam maupun potensi yang dimiliki manusianya. Potensi bidang pertanian dan perdagangan menjadi daya dukung Desa Kerobokan. Hal ini menjadi tantangan bagi pengembangan pembangunan di segala sektor wilayah Desa Kerobokan, oleh sebab itu segala potensi yang ada tentunya harus dioptimalkan agar Desa Kerobokan menjadi desa yang mandiri dan dapat mewujudkan otonomi desa sebagaimana yang diamanatkan dalam UU No. 6 Tahun 2014.

Berdasarkan wawancara yang dilakukan, pemerintah desa selalu menetapkan strategi agar saling berkoordinasi dengan semua pelaku terutama pengelola dan pihak pemerintah desa serta BPD. Dengan koordinasi dan kerjasama yang baik maka tujuan untuk dapat meningkatkan perekonomian desa dapat dilakukan dengan teratur dan terstruktur di masing-masing pengelolaannya. Dalam rangka mewujudkan pembangunan desa, maka salah satu alternatif yang dilakukan adalah mengembangkan pendapatan asli desa. Sumber pendapatan asli desa akan menghasilkan output secara maksimal bagi pemerintah desa jika ditunjang dengan strategi yang digunakan pemerintah desa dalam mengelola pendapatan asli desa. Berbagai strategi dibutuhkan dalam mengelola pendapatan desa supaya efektif dan bermanfaat bagi masyarakat yaitu identifikasi dan inventarisasi nilai dan potensi kekayaan desa. Identifikasi dan inventarisasi nilai dan potensi kekayaan desa merupakan tahap proses mengetahui jumlah dan nilai kekayaan yang dimiliki desa, baik yang saat ini dimanfaatkan maupun yang masih berupa potensi yang belum dimanfaatkan. kegiatan ini merupakan dimaksudkan untuk memperoleh informasi yang akurat, lengkap, dan mutakhir mengenai kekayaan yang dimiliki oleh Desa Kerobokan. Hal tersebut sesuai dengan Undang-Undang no. 6 tahun 2014 pasal 77 ayat 2 tentang aset desa.

Strategi yang telah dilakukan Desa Kerobokan dalam proses identifikasi dan inventarisasi adalah dengan melakukan perencanaan pembangunan dilakukan berdasarkan musyawarah bersama yakni Musrenbang-Desa yang terdiri dari pemerintah desa, tokoh masyarakat, dan BPD. Alur selanjutnya yaitu pembuatan peraturan desa, setelah peraturan desa sudah ditetapkan maka langkah selanjutnya yaitu proses pengajuan pembangunan ke Badan Perencanaan Pembangunan Daerah Buleleng (Bappeda). Sehingga potensi pendapatan asli desa yang dimiliki Desa Kerobokan dapat berkembang yang terdiri dari: 1) tanah kas desa 2) tanah hibah 3) penampung air 5) desa wisata serta 4) pengelolaan sampah. Sehingga dengan adanya identifikasi terkait kekayaan pendapatan asli desa yang dimiliki, maka desa bisa mengelola 
dan mengembangkan pendapatan asli desanya secara maksimal. Dengan hasil pendapatan asli desa dapat pula pemerintah desa diharapkan mampu mengembangkan sarana prasarana untuk mendukung lajunya kebutuhan masyarakat terutama di bidang perdagangan, pertanian serta pariwisata. Perlunya sistem informasi manajemen kekayaan desa untuk mendukung pengelolaan kekayaan desa secara efisien dan efektif serta menciptakan transparansi kebijakan pengelolaan kekayaan desa, maka pemerintah desa perlu memiliki atau mengembangkan sistem informasi manajemen yang komprehensif dan handal sebagai alat untuk pengambilan keputusan.

Sistem informasi manajemen Desa Kerobokan terkait pengelolaan pendapatan asli desa berupa database kekayaan yang dimiliki oleh desa, yang terdiri dari iventarisasi sumber pendapatan yang diperoleh dari pendapatan asli desa, perolehan hasil pengelolaan pendapatan asli desa tiap tahun, peningkatan pendapatan asli desa, struktur organisasi pengelola pendapatan asli desa. Sistem informasi manajemen bermanfaat untuk dasar pengambilan keputusan mengenai kebutuhan pengadaan barang dan estimasi kebutuhan belanja pembangunan dalam penyusunan anggaran pembangunan desa serta bermanfaat untuk menghasilkan laporan pertangggungjawaban kepada pemerintah daerah maupun kepada masyarakat. Sistem informasi manajemen Desa Kerobokan lebih menekankan pada kelengkapan database meskipun hanya sekadar database secara manual sebagai laporan pertanggungjawaban kepada pemerintah daerah kabupaten. Untuk pertanggungjawaban dan transparansi kepada masyarakat sudah terlaksana terkait pemerintah desa sudah menyediakan akses terbuka seperti salah satunya adalah website resmi Desa Kerobokan, dan juga secara transparan masyarakat desa dapat hadir di dalam rapat terkait pertanggungjawaban keuangan desa. Sehingga sistem informasi manajemen dalam pengelolaan pendapatan asli desa Kerobokan sudah maksimal dalam penyampaian informasi kepada masyarakat. Pengawasan dan pengendalian pemanfaatan kekayaan desa, sangat penting dilakukan untuk menilai konsistensi antara praktik yang dilakukan pemerintah desa dengan standar yang berlaku. Pengawasan diperlukan untuk menghindari penyimpangan dalam perencanaan maupun pengelolaan kekayaan yang dimiliki desa. Untuk meningkatkan fungsi pengawasan pengelolaan pendaptan asli desa, Desa Kerobokan memakai peran masyarakat sebagai pengawasan secara langsung yakni dengan memberdayakan masyarakat sebagai pengelola pendapatan asli desa yang terbentuk dalam tim khusus. Peran masyarakat dalam pengelolaan pendapatan asli desa di Desa Kerobokan merupakan bentukan dari kepala desa dan perangkat desa sebagai tim pengelola serta pelaksana yang bertanggungjawab terhadap pemerintah desa. Sistem pengawasan ini berjalan secara optimal. Hal ini disebabkan karena adanya keterlibatan secara langsung masyarakat sebagai pengelola dan pengawas. Selain itu pengawasan dan pengendalian pemanfaatan kekayaan desa dengan cara diatas terbukti efektif karena masyarakat dirasa lebih berperan aktif dalam keikutsertaan membangun desa melalui pengelolaan pendapatan asli desa. Keterlibatan jasa penilai dalam otonomi desa pemerintah desa memiliki wewenang yang lebih besar untuk mengelola kekayaan desanya, untuk itu pemerintah desa dituntut untuk dapat mengelola kekayaan desa secara profesional. Kunci keberhasilan dari pemerintah Desa Kerobokan dinilai dari sejauh mana hasil kinerja yang telah dilakukan, maka diperlukan jasa penilai sebagai bentuk evaluasi dalam kinerja pemerintah Desa Kerobokan.

Strategi pengelolaan pendapatan asli desa dalam meningkatkan pembangunan Desa Kerobokan Kecamatan Sawan Kabupaten Buleleng merupakan strategi yang tepat dalam meningkatnya pendapatan asli desa, begitu pula dengan pendapatan asli desa yang mampu memberikan sumber pemasukan secara meningkat tiap tahunnya juga dapat mempengaruhi dalam proses pembangunan desa. Berdasarkan observasi di atas menunjukkan bahwa adanya peningkatan pembangunan desa secara fisik yaitu dengan adanya pengaspalan jalan sepanjang $5 \mathrm{~km}$ yang sudah terealisasi guna untuk kelancaran masyarakat desa dalam kegiatan sehari-harinya, selain itu peningkatan pendapatan lainnya juga terkelola secara efektif sehingga memberikan dampak positif terhadap kemajuan desa dan kesejahteraan masyarakat Desa Kerobokan. Sejalan dengan pembangunan desa dari segi aspek fisik, pembangunan sumberdaya manusia Desa Kerobokan juga mengalami peningkatan khususnya dalam pengembangan usaha ekonomi melalui pelatihan pengembangan produk lokal. Masyarakat diberikan pelatihan-pelatihan yang sesuai untuk bisa mengembangkan produk-produk lokalnya. Sehingga dapat disimpulkan bahwa Desa Kerobokan dapat membangun, memanfaatkan, dan mengeksplorasi dengan tepat (optimal, efektif, dan efisien). Dimana segala potensi dan sumber daya yang telah dimiliki desa mampu memberikan manfaat bagi kesejahteraan masyarakat dan memberikan perubahan kearah yang lebih baik.

\section{Simpulan dan Saran}

Sumber pendapatan Desa Kerobokan dalam membiayai kegiatan pembangunan berasal dari pendapatan asli desa, Alokasi Dana Desa (ADD) dan bantuan keuangan dari Pemerintah Daerah 
Kabupaten Buleleng. Sumber pendapatan desa yang berupa Pendapatan Asli Desa (PADes) dapat dioptimalkan oleh pemerintah desa agar dapat menambah jumlah pendapatan. BUMDes merupakan lembaga usaha yang bergerak dalam bidang pengelolaan aset-aset dan sumberdaya ekonomi desa dalam kerangka pemberdayaan masyarakat desa. Dengan kehadiran BUMDes ini diharapkan desa menjadi lebih mandiri dan masyarakatnya pun menjadi lebih sejahtera. Peran BUMDes diperlukan untuk meningkatkan pendapatan asli desa agar desa dapat memanfaatkan potensi-potensi yang ada di Desa Kerobokan dengan baik sehingga dapat meningkatkan jumlah pendapatan asli desa dan pendapatan desa.

Dalam rangka mewujudkan pembangunan desa, maka salah satu alternatif yang dilakukan adalah mengembangkan pendapatan asli desa. Sumber pendapatan asli desa akan menghasilkan output secara maksimal bagi pemerintah desa jika ditunjang dengan strategi yang digunakan pemerintah desa dalam mengelola pendapatan asli desa. Berbagai strategi dibutuhkan dalam mengelola pendapatan desa supaya efektif dan bermanfaat bagi masyarakat yaitu identifikasi dan inventarisasi nilai dan potensi kekayaan desa dengan melakukan perencanaan pembangunan dilakukan berdasarkan musyawarah bersama yakni Musrenbang-Desa. Mengembangkan sarana prasarana untuk mendukung lajunya kebutuhan masyarakat terutama di bidang perdagangan, pertanian serta pariwisata. Perlunya sistem informasi manajemen kekayaan desa untuk mendukung pengelolaan kekayaan desa secara efisien dan efektif serta menciptakan transparansi.

Penelitian ini disarankan dapat dikembangkan untuk penelitian selanjutnya dengan desain kuantitatif dengan mengembangkan variable-variabel optimalisasi, profesionalisme ataupun sumber daya manusia dan kompetensinya dengan mengambil beberapa desa sebagai sampel penelitian sehingga lebih dapat untuk digeneralisasi.

\section{Daftar Rujukan}

Atmadja, A.T., K.A.K. Saputra and M.K. Koswara. (2018). The Influence Of Village Conflict, Village Apparatus Ability, Village Facilitator Competency And Commitment Of Local Government On The Success Of Budget Management. Academy of Accounting and Financial Studies Journal, Vol. 22, No.1, 2018.

Atmadja, Anantawikrama Tungga dan K.A.K. Saputra. (2017). Pencegahan Fraud dalam Pengelolaan Keuangan Desa. Jurnal Ilmiah Akuntansi dan Bisnis, Vol. 12, No. 2, Halaman: 7-16.

Atmadja, A.T. and K.A.K. Saputra (2018). Determinant Factors Influencing TheAccountability Of Village FinancialManagement. Academy of Strategic Management Journal, Volume 17, Issue 1, 2018.

Dewi, Putu Eka Dianita Marvilianti., Komang Adi Kurniawan Saputra dan MadeAristia Prayudi. (2017). Hubungan Kualitas Pengelolaan Aset Desa dan Pendapatan Asli Desa (Studi pada Desa-desa di Kabupaten Buleleng-Bali). Proceeding SENARI 5, Halaman: 253-260.

Peraturan Menteri Dalam Negeri Republik Indonesia Nomor 113 Tahun 2014 Tentang Pengelolaan Keuangan Desa

Peraturan Menteri Keuangan Republik Indonesia Nomor 250 Tahun 2014 Tentang Pengalokasian Transfer ke Daerah dan Dana Desa.

Peraturan Pemerintah Republik Indonesia Nomor 72 Tahun 2005 tentang Desa

Rasjid, Herlina dan Harun Blongkod. (2016). Peningkatan Kapasitas Aparatur Desa dalam Pengelolaan Keuangan Desa di Desa Juriya Kecamatan Blato Kabupaten Gorontalo Provinsi Gorontalo. Lembaga Penelitian dan Pengabdian Masyarakat Universitas Negeri Gorontalo.

Saputra, K.A.K dan I.P. Julianto. (2016). Pembentukan Bumdesa Dan Komunitas Wirausaha Untuk Meningkatkan Pembangunan Ekonomi Di Desa. Prosiding Seminar Nasional TEAM, Universitas Pendidikan Ganesha.

Saputra, K.A.K., P.B. Anggiriawan dan I.N. Sutapa. (2018). Akuntabilitas Pengelolaan Keuangan Desa Dalam Perspektif Budaya Tri Hita Karana. Jurnal Riset Akuntansi dan Bisnis Airlangga Vol. 3. No. 1 (2018) 306-321

Sugiyono. (2009). Metode Penelitian Bisnis. Alfabeta, Bandung.

Sujarweni, V. Wiratna. (2015). Akuntansi Desa: Panduan Tata Kelola Keuangan Desa. Penerbit: Pustaka Baru Press, Yogyakarta.

Undang-undang Republik Indonesia Nomor 6 Tahun 2014 Tentang Desa

Wardoyo, Hasto. (2015). Penguatan Pengelolaan Keuangan Desa dan Optimalisasi Peran BUMDesa sebuah upaya menuju Desa Mandiri dan Kredibel di Kabupaten Kulon Progo.Seminar Nasional Temu Forum Dosen Akuntansi Sektor Publik 2015, Universitas Atma Jaya Yogyakarta.

Yabbar, Rahmah dan Ardi Hamzah. (2015). Tata Kelola Pemerintahan Desa: Dari Peraturan di Desa hingga Pengelolaan Badan Usaha Milik Desa, Dari Perencanaan Pembangunan Desa hingga Pengelolaan Keuangan Desa. Penerbit: Pustaka, Surabaya. 